\title{
Living by the Laws of Nature
}

Levy $\mathbf{M}^{*}$

Point of life, USA

*Corresponding author: Michael Levy, 4900 North Ocean bvd Fort Lauderdale FL, USA,

Tel: 9547858439; Email: mikmikl@aol.com

\section{Commentary}

Volume 1 Issue 2

Received Date: December 05, 2018

Published Date: December 17, 2018

DOI: $10.23880 /$ phij-16000110
Can our religious and scientific teachings help humanity to live a more authentic life in our modern breakneck-paced world? Well, let's become archaeologists and dig some genuine meaning out of the Bible.

"In the beginning there was light." Without light nothing can grow. The Sun provides earth with light...And God said; "it was all good." When we read the first few chapters in the Bible, we possess the opportunity to decode the story of Adam and Eve. This will supply us with a formula that adheres to the laws of nature/spirit/universe..... so that all humanity can prosper in peaceful harmony.

When Eve handed Adam the apple from the Tree of Knowledge, Adam ate the forbidden fruit. They were both evicted from paradise by an angry landlord. They broke a house rule. Now we can believe the story as is, or we can search a little deeper and find out what the author really meant by the story of Adam and Eve's disobedience.

Eating forbidden fruit is a symbolic phrase meaning, we are doing something that goes against the Laws of Nature. Since the tabooed fruit came from the Tree of Knowledge, it must mean that something unsavory happened to the whole of humanity many years ago. Something effectuated humanities eviction from paradise.

Now; what is it that lives in all our minds and takes away our happiness, peace of mind and contentment? What takes away our personal paradise? We do not have to search too far to find the answer.

Negative emotions that produce stressful reactions in our bodies are the forbidden fruits we digest every day of our lives. Most people die of dis-ease related illness. Despite being kept alive for many years on medications that have bad side effects, people still die of a dis-ease. Therefore; the only real cure from disease is to stop all the negative emotions.
We need to locate our endowed keys which unlock the gates into paradise. We need to reinstate our minds into a sanctuary of happiness, peace of mind and contentment. For that is the domicile nature designated humanity to inhabit. I doubt if there is not one sane person on planet earth that does not want to live in paradise. Most will say it is impossible, but nevertheless their first wish would be to live a happy, healthy life.

Let's get back to the Genesis of earth. In the beginning there was light (Sun, heat) Then there was volcanic actions as earth began to cool (fire.) Through the evolutionary process within the erosion of rocks (weather, fungi, bacteria, etc.,) soil was formed, permeated with a mass of organic life. In just one teaspoon of fertile soil exists forty-thousand different species of organic life.

Within each specie lives one-hundred-million living organisms. A whole universe in one small spoon of dirt with the heat from the sun and the water of the oceans, life seeded in the soil begins to grow. The rain (water) cultivated the soil and it began to grow ferns and vegetation.

The growth became jungle congested with weeds and many plants that held back many more beautiful, exotic plants from growing. The seeds of exotic plants had been planted by evolution, but they found it difficult to grow because the stronger weeds held their space. Strong storms (water) and heat waves (fire) reduced the weeds to ashes and this gave the beautiful exotic plants the opportunity to blossom and flourish. In nature, destruction shapes construction.

From the spark within the seed came the bud...From the spark within the bud grew the flower. From the life within the flower...The seed. And so the cycle continues, all without the aid of humans. Flowers live in paradise, so why aren't humans as intelligent as flowers? Humans are 
also grown from Spirits seed. So what ignorance is holding back humanities growth?

Just as the butterfly learnt how to escape from its cocoon, so humanity must learn how to escape from eating forbidden fruit (negativity). If anyone would help the butterfly from escaping from its cocoon, the butterfly would perish before it can escape and fly. It must withstand its ground (not violently struggle against nature) and wait for the cocoon to eventually weaken to set itself free. As it prods its way through the cocoon, it builds up the muscle and strength to exist as a beautiful butterfly. It enjoys the stages of metamorphism as it transforms into a beautiful butterfly.

No matter what hand life deals us, we must enjoy every experience. The negative emotions we digest are the weeds in our life that we need to grow through. They were not part of our original make up, for in the beginning "All Was Good" It only became bad when we stared to become more sophisticated and use our intellect in many ways nature did not intend. This gave rise to the "bad" things in life. The "bad things" are our hatreds, jealousies, anger, dogmas, selfishness etc.

If we could do an internal inspection on our intellectual brain, it would communicate that the emotions are real and the intellect is the master decision maker. But, if we could do a search on past generations, two million years ago, with similar brains, we would probably find there was a time when the brain only contained intelligence. The intellect/ego was just a good idea waiting to form itself. We have come a long way since then, but is it progress to sacrifice our happiness and simplicity?

Humanity has to accept the true facts of life. The intellect-ego is a learning tool of the mind to enhance our understanding of universal intelligence. It decodes intelligence that has always existed, even before the cosmos began. The intellect should not be a dominant force that shepherds human life into emotional distress.

In the real estate world there are three golden rules......Location, location, location. And so it is with our minds. Where do we wish our thoughts to be located? In the Intellect/ego that is keen on eating many forbidden fruits (inauthentic information.) Or, do we wish to locate our thoughts in paradise, where nature's intelligence blends magnificently with human intelligence/intellect/ego. All for one and one for all.

Location-Location-Location.......

Location one......Humanity can blossom as a radiant heavenly Orchid

Location two......Humanity can emit the aura of fragrant celestial Jasmine

Location three Humanity can feel as velvety as a divine rose petal.

Is it time you launch your beautiful intelligent wings of your mind and transform into a creative, ingenious human butterfly?

The location of your thoughts depend on who's garden you wish to plant the seeds of prosperity.

The solo intellects/egos world of "bad" or Natures/Spirits world of "Good" that guides the ego/intellect into paradise. Time to get out the excavator and do a little digging in the fields of authentic thought....... Located in the exotic paradise gardens of your mind. Reap your harvest of Joy from the Love seeds you plant.

Treasure people as you yourself would like to be savored. Allow the blossom of your smile to enliven all your fellow human prime mates. Learn the meaning of the word JOY and start to.... enjoy yourself, it's later than you think! 